\title{
Effect of Variation in Food Components and Composition on the Antimicrobial Activity of Oregano and Clove Essential Oils in Broth and in a Reformulated Reduced Salt Vegetable Soup Product
}

\author{
Anna M. Witkowska ${ }^{1}$, Dara K. Hickey ${ }^{1} \&$ Martin G. Wilkinson ${ }^{1}$ \\ ${ }^{1}$ Department of Life Sciences, University of Limerick, Castletroy, Limerick, Ireland \\ Correspondence: Martin G. Wilkinson, Department of Life Sciences, University of Limerick, Castletroy, \\ Limerick, Ireland. Tel: 353-061-213-440. E-mail: martin.wilkinson@ul.ie
}

Received: March 12, 2014 Accepted: July 15, 2014 Online Published: August 14, 2014

doi:10.5539/jfr.v3n6p92 URL: http://dx.doi.org/10.5539/jfr.v3n6p92

\begin{abstract}
The objective of this study was to determine and quantify the influence of various food components (carbohydrates, fat, protein or $\mathrm{NaCl}$ contents) or chemical properties $(\mathrm{pH}$, water activity levels) on the antimicrobial efficacy of oregano and clove essential oils (EOs). Growth of Listeria innocua or Escherichia coli treated with oregano or clove EOs was monitored following separate addition of various food components. Antimicrobial activity of EOs was enhanced in presence of $\mathrm{NaCl}(\geq 0.5 \mathrm{~g} / 100 \mathrm{ml})$, or in media with low $\mathrm{pH}$ values $(\leq 5.0)$, especially when adjusted with organic acids. Enhanced antimicrobial activity was observed following reduction in water activity, which appeared related to the nature of solute used. Antibacterial activity of EOs was reduced in presence of vegetable oil ( $\geq 1 \mathrm{ml} / 100 \mathrm{ml})$, protein $(\geq 1 \mathrm{~g} / 100 \mathrm{ml})$ or starch $(\geq 10 \mathrm{~g} / 100$ $\mathrm{ml})$. Based on data obtained, the composition of vegetable soup was altered to optimise the efficacy of EOs, by lowering the $\mathrm{pH}$ to 5.0 using citric acid. A combination of oregano EO and acidification appeared to control growth of L. innocua and E. coli during storage at 4 or $10^{\circ} \mathrm{C}$. Thus, reformulation treatments including EO addition should be considered to improve the shelf-life of chilled ready meals.
\end{abstract}

Keywords: antimicrobial, essential oils, food ingredients, composition, interactions

\section{Introduction}

Herbs and spices have been used for centuries to add flavor and extend the shelf-life of a wide variety of foods. However, there has been a renewal of interest in the antimicrobial properties of these compounds as a consequence of changes in legislation and consumer trends that demand foods remain as preservative free as possible but are still safe and convenient to use (Brul \& Coote, 1999). Salt has been used routinely as a flavouring and preservative agent in food products. However addition of salt to foodstuffs has become a major issue for the processed food sector, as processed foods, including chilled ready meals are a leading contributor to salt intake worldwide (Desmond, 2006). Recent reports from the Food Safety Authority of Ireland (FSAI, 2005) and the Food Standards Agency in the UK (SACN, 2003) have shown that the average daily sodium (salt) intake from foods in Irish and UK adults has been estimated as 3.3-3.9 $\mathrm{g}$ (8.3-10 g salt). It is now recommended by public health agencies that adults reduce their daily salt intake to a target of $6 \mathrm{~g}$ (FSAI, 2003; SACN, 2003) due to association between excessive sodium intake and the development of osteoporosis, kidney failure, and hypertension, leading to increased risk of cardiovascular disease (MacGregor \& de Wardener, 2002). Therefore, it has been recommended by various health organizations worldwide to reduce sodium intake of the general population, through a reduction of the salt content in processed foods (Consensus Action on Salt \& Health, 2012; FSAI, 2003). As a result, food manufacturers are attempting to introduce into market new products labelled as "low salt ready meals". However the removal of sodium chloride from complex food systems may have implications for microbiological and sensory quality. Therefore a possible application of herb and spice preparations may be in controlling pathogens and food spoilage bacteria to assure consumer safety and to compensate for any possible loss in flavor impact (Burt, 2004; Prakash, Singh, Kedia, \& Dubey, 2012).

Among the many essential oils evaluated in broth media, those from oregano (Origanum vulgare) or clove (Syzygium aromaticum) have been shown as being particularly active against both Gram-positive and Gram-negative bacteria (Burt \& Reinders, 2003; Moreira, Ponce, del Valle, \& Roura, 2005). Their antimicrobial 
properties have been attributed to phenolic compounds, in particular, carvacrol and eugenol which are principal components of oregano and clove, respectively (Deans \& Ritchie, 1987). These phytophenols exert antibacterial effects by disruption of cytoplasmic membrane leading to leakage of ions, ATP, nucleic acids, amino acids, impairment of respiratory activity of bacteria and enzyme inhibition preventing substrate utilization for energy production (Holley \& Patel, 2005; Lv, Liang, Quan, \& Li; 2011; Witkowska, Hickey, Alonso-Gomez \& Wilkinson, 2013). The efficacy of EOs and extracts of herbs and spices in vitro is often much greater than in food systems (Burt, 2004; Glass \& Johnson, 2004). To produce a similar effect to that reported in vitro the following increases in addition rates were required in foods: two-fold in semi-skimmed milk (Karatzas, Kets, Smid, \& Bennik, 2001), 10-fold in pork sausages (Pandit \& Shelef, 1994), 25- to 100-fold in Spanish soft cheese and 50-fold in mushroom soup (Ultee \& Smid, 2001). As most foods consist of carbohydrates, proteins, fats, salt, and water it is important to determine the effect of these components on the antimicrobial properties of any proposed added EO preparation to enable their successful application (Devlieghere, Vermeulen, \& Debevere, 2004). Despite the drive towards a reduction in salt content in foods for dietary reasons and consequently the enhanced use of herb and spice preparations such as EOs, there is still very little published information available on the effect of the main food constituents or food chemical properties on the antimicrobial activity of EOs, as well as on application of EOs in combinations with other preservation techniques in reduced salt ready meals.

Hence, the objectives of this study were to: (i) evaluate the antimicrobial effect of commercial oregano and clove EOs against Listeria innocua and Escherichia coli in broth model media or in a reduced salt chilled vegetable soup product, (ii) to determine and quantify the influence of various food components and food chemical properties on the antimicrobial efficacy of EOs, (iii) to evaluate the effect of type of acid used to adjust the $\mathrm{pH}$ of growth medium, (iv) to optimise the antimicrobial efficacy of plant EOs by reformulation of a reduced salt vegetable soup.

\section{Materials and Methods}

\subsection{Materials}

Oregano (Origanum vulgare) and clove (Syzygium aromaticum) EOs, rapeseed oil, sunflower oil, 2M HCl, 2M citric acid, and 2M NaOH were purchased from Sigma-Aldrich (Steinheim, Germany). Whey protein concentrate (WPC) containing $75.8 \mathrm{~g} / 100 \mathrm{~g}$ protein was kindly supplied by Carbery Food Ingredients (Ballineen, Cork, Ireland). Water soluble starch was purchased from Becton Dickinson (Sparks, Maryland, USA), while $\mathrm{NaCl}$, sucrose, glucose, $85 \%$ lactic acid, glycerol, 99.8\% acetic acid were purchased from Merck (Darmstadt, Germany).

\subsection{Microorganisms and Growth Conditions}

Bacterial cultures of Listeria innocua ATCC 33090, and Escherichia coli ATCC 11303 used in the present studies were obtained from the American Type Culture Collection (ATCC). Stock cultures were maintained at $-80^{\circ} \mathrm{C}$ in cryovials (Technical Service Consultants Ltd., Lancashire, UK) and sub-cultured twice onto Tryptone Soya Agar (TSA, Oxoid, Basingstoke, UK) followed by incubation at $37{ }^{\circ} \mathrm{C}$ for $24 \mathrm{~h}$. Working cultures were prepared from subcultures and grown for $18 \mathrm{~h}$ at $37{ }^{\circ} \mathrm{C}$ in Tryptone Soya Broth medium (TSB, Oxoid, Basingstoke, UK).

\subsection{Minimum Inhibitory Concentration (MIC) of Essential Oilss in Broth Systems}

MIC values were determined using a microdilution broth method in 96-well microplates (Sarstedt, Numbrecht, Germany). Briefly, oregano or clove EOs were tested using two-fold serial dilution method over a range of concentrations from 0.5 to $0.015625 \mathrm{ml} / 100 \mathrm{ml}(0.5,0.25,0.125,0.0625,0.03125$ and $0.015625 \mathrm{ml} / 100 \mathrm{ml})$ against overnight broth cultures of Listeria innocua ATCC 33090, and Escherichia coli ATCC 11303 grown to a population $5 \times 10^{5} \mathrm{CFU} / \mathrm{ml}$ in TSB. Microplates were incubated at $37^{\circ} \mathrm{C}$ and growth was monitored by measuring absorbance at $600 \mathrm{~nm}$ every $30 \mathrm{~min}$ over $18 \mathrm{~h}$, using a microplate reader (Biotek Instruments Inc, Highland Park, VT, USA). MIC was defined as the lowest concentration of the essential oil which completely inhibited bacterial growth.

\subsection{Determination of Antimicrobial Effects of Oregano and Clove Essential Oils in a Reduced Salt Vegetable Soup}

Antimicrobial efficacy of oregano and clove EOs was evaluated in a reduced salt ready meal vegetable soup, produced on a $500 \mathrm{~kg}$ commercial scale by Dawn Fresh Foods (Fethard, Tipperary, Ireland) as described by Mitchell, Brunton and Wilkinson, $(2011,2013)$. The product was obtained from the factory after production, chilled and stored at $4{ }^{\circ} \mathrm{C}$ prior to analysis. The formulation consisted of a blend of ingredients including: potatoes, carrots, turnips, celery, diced onions, vegetable stock, and water. The approximate composition was: 
protein $0.79 \mathrm{~g} / 100 \mathrm{~g}$, carbohydrate $6.44 \mathrm{~g} / 100 \mathrm{~g}$, fat $2.72 \mathrm{~g} / 100 \mathrm{~g}, \mathrm{NaCl} 0.46 \mathrm{~g} / 100 \mathrm{~g}, \mathrm{pH} 6.20, \mathrm{a}_{\mathrm{w}} 0.994$. Vegetable soup was first microwaved for $3 \mathrm{~min}$ at $800 \mathrm{~W}$ to eliminate any background microflora and was immediately transferred to stomacher bags in $25 \mathrm{~g}$ portions. Initially, oregano and clove EOs were added to the soup at the range of concentrations used to determine MICs in broth media $(0.015625 \mathrm{ml} / 100 \mathrm{ml}-0.5 \mathrm{ml} / 100 \mathrm{~g})$, however at these levels considerable antimicrobial effect could not be obtained (data not shown), thus oregano and clove EOs were added to achieve higher final concentrations of $0.0625,0.125,0.25,0.5,1.0,2.0$, and 4.0 $\mathrm{ml} / 100 \mathrm{~g}$. Samples were left to cool to ambient temperature $\left(\sim 21^{\circ} \mathrm{C}\right)$ and were then inoculated with overnight cultures of L. innocua ATCC 33090 or E. coli ATCC 11303 to a final level of approximately $5 \times 10^{5} \mathrm{CFU} / \mathrm{g}$. Uniform distribution of the EO was ensured by mechanical treatment for one minute in a stomacher lab-blender (Seward Medical, London, UK). Controls included soup without added EOs as well as uninoculated soup with added EOs to detect any possible contamination by background microflora that might have survived cooking process and microwave treatment. Samples were sealed and stored at a non-restrictive growth temperature of 25 ${ }^{\circ} \mathrm{C}$ for $24 \mathrm{~h}$. Subsequently, $25 \mathrm{~g}$ portions were homogenized for two minutes, in a stomacher lab-blender with 225 $\mathrm{ml}$ of sterile solution of $0.1 \mathrm{~g} / 100 \mathrm{ml}$ peptone water (Oxoid, Basingstoke, UK). $0.1 \mathrm{ml}$ of each suspension was then serially diluted up to $10^{-5}$ in peptone water and $0.1 \mathrm{ml}$ aliquots were spread on TSA plates, which were further incubated for up to $48 \mathrm{~h}$ at $37^{\circ} \mathrm{C}$. Results were expressed as $\log \mathrm{CFU} / \mathrm{g}$.

\subsection{Effects of Food Components, and Chemical Parameters on Antimicrobial Activity of Essential Oils}

The effect of different food components, $\mathrm{pH}$ or water activity $\left(\mathrm{a}_{\mathrm{w}}\right)$ on the antimicrobial properties of EOs, was evaluated by following the growth of L. innocua ATCC 33090 and E. coli ATCC 11303 in TSB medium (30 g/L, $\mathrm{pH} 7.2)$ with varying added concentrations of clove or oregano EOs $(0.5 \times \mathrm{MIC}, \mathrm{MIC}, 2 \times \mathrm{MIC})$ with separate addition of the differing levels of protein from whey protein concentrate (WPC), $\mathrm{NaCl}$, starch, rapeseed oil or sunflower oil.

For investigation of the effects of added WPC proteins, the $\mathrm{pH}$ of suspensions in distilled water was adjusted to 3.0 with $\mathrm{HCl}$ to avoid gel formation during sterilization, and adjusted back to $\mathrm{pH} 7.2$ with sterile $2 \mathrm{M} \mathrm{NaOH}$ after autoclaving and cooling to room temperature $\left(\sim 21^{\circ} \mathrm{C}\right)$. Sterile WPC suspensions were then mixed with equal amounts of double-strength TSB to give final protein concentrations of $0,1,3,5 \mathrm{~g} / 100 \mathrm{ml}$.

To investigate the effects of added salt, sterilized salt solutions in distilled water were mixed with equal amounts of double-strength TSB to give final $\mathrm{NaCl}$ concentrations of $0,0.1,0.5,1,3$, or $5 \mathrm{~g} / 100 \mathrm{ml}$.

To investigate the effect of added carbohydrates, solutions of water soluble starch were autoclaved and mixed with equal amounts of double-strength TSB after cooling to room temperature $\left(\sim 21^{\circ} \mathrm{C}\right)$, to give final carbohydrate concentrations of $0,1,5,10$ or $20 \mathrm{~g} / 100 \mathrm{ml}$.

To investigate the effect of fat, rapeseed oil, or sunflower oil were autoclaved separately, mixed with sterile water and double-strength TSB using a sterile hand blender (Moulinex, Paris, France) to give final oil concentrations of $0,1,5,10$, and $30 \mathrm{ml} / 100 \mathrm{ml}$. Sterile Tween 80 was added at $0.5 \mathrm{ml} / 100 \mathrm{ml}$ in order to facilitate mixing and to stabilize emulsions (Devlieghere et al., 2004).

To investigate the effect of water activity $\left(\mathrm{a}_{\mathrm{w}}\right)$, equal amounts of double-strength TSB were mixed with: sterile solutions of $\mathrm{NaCl}$ ranging from $0,4,8$, and $16 \mathrm{~g} / 100 \mathrm{ml}$ to give $\mathrm{a}_{\mathrm{w}}$ values of $0.997,0.975,0.949$, or 0.876 , respectively, sucrose solutions ranging from $0.75,26$ or $46 \mathrm{~g} / 100 \mathrm{ml}$ to give $\mathrm{a}_{\mathrm{w}}$ values of $0.997,0.988,0.975$ and 0.952 , respectively, and glycerol solutions ranging from $0,4,8,20$ or $30 \mathrm{ml} / 100 \mathrm{ml}$ to give $\mathrm{a}_{\mathrm{w}}$ values of 0.997 , $0.99,0.977,0.948$, and 0.911 , respectively. The values for $\mathrm{a}_{\mathrm{w}}$ of the different samples were measured using an AquaLab water activity meter (Decagon Devices, Pullman, USA).

To evaluate the effect of $\mathrm{pH}$ on antimicrobial activity of essential oils, $\mathrm{pH}$ of single-strength TSB was adjusted to 4.0, 5.0, 6.0, 7.0, and 8.0 with sterile $2 \mathrm{M} \mathrm{HCl}$ or $2 \mathrm{M} \mathrm{NaOH}$ solutions. Subsequently, the influence of the particular acid used to adjust the $\mathrm{pH}$ of growth medium on antimicrobial properties of EOs was evaluated. In this case, the $\mathrm{pH}$ of TSB medium supplemented with oregano or clove EOs at their respective MICs, was adjusted to 5.0 using hydrochloric, citric, lactic or acetic acids.

For all experiments, except that regarding the influence of $\mathrm{pH}$, the $\mathrm{pH}$ of each medium was adjusted to 7.2 with either $2 \mathrm{M} \mathrm{HCl}$ or $2 \mathrm{M} \mathrm{NaOH}$ solutions. $10 \mathrm{ml}$ samples of each of these solutions were finally inoculated with $100 \mu \mathrm{l}$ of a diluted overnight suspension of bacterial cultures to give approximately $5 \times 10^{5} \mathrm{CFU} / \mathrm{ml}$, and incubated at $37{ }^{\circ} \mathrm{C}$ for $24 \mathrm{~h}$. Controls included samples with added food ingredients only, to determine whether they had any individual influence on bacterial growth and samples with EOs only. For each suspension $0.1 \mathrm{ml}$ was then serially diluted up to $10^{-6}$ in peptone water and $0.1 \mathrm{ml}$ aliquots spread on to TSA plates, which were further incubated for up to $48 \mathrm{~h}$ at $37^{\circ} \mathrm{C}$. Results were expressed in $\log \mathrm{CFU} / \mathrm{ml}$. 


\subsection{Application of Oregano Essential Oil in Vegetable Soup With Reformulated Composition During Chilled Storage}

The $\mathrm{pH}$ of vegetable soup produced by Dawn Fresh Foods (Fethard, Tipperary, Ireland) was adjusted to 5.0 using citric acid, as this acid is routinely used by the manufacturer to alter $\mathrm{pH}$ of all the meals produced, chilled immediately and stored at $4{ }^{\circ} \mathrm{C}$ prior to the experiment. Simultaneously, another batch of vegetable soup (pH 6.2) was produced also chilled immediately and stored at $4{ }^{\circ} \mathrm{C}$ prior to the experiment. Oregano oil was added to $25 \mathrm{~g}$ portions of soup previously microwaved to a final concentration of $0.25 \mathrm{ml} / 100 \mathrm{~g}$. Samples were inoculated with $L$. innocua or E. coli as previously described (section 2.4) and stored at a refrigeration temperature of $4^{\circ} \mathrm{C}$ or at an abuse temperature of $10^{\circ} \mathrm{C}$ for 9 days. Growth was monitored on day $1,3,6$, and 9 of storage by plate counts on TSA plates, as described earlier (section 2.4).

\subsection{Statistical Analysis}

All experiments were replicated three times and each treatment was run in duplicate. Data represents means \pm standard deviations. Statistical analysis was performed by Analysis of variance (ANOVA) using GraphPad Prism Version 4.03 statistical software (GraphPad Software, San Diego California USA). Level of significance was set at $\mathrm{P}<0.05$. Means were compared using Tukey's multiple comparision tests to determine the effect of variation in food components and chemical properties on the antimicrobial activity of EOs.

\section{Results and Discussion}

\subsection{Minimum Inhibitory Concentration (MIC) of Eos in Broth Systems}

In this study, oregano oil showed MIC values of $0.0625 \mathrm{ml} / 100 \mathrm{ml}$ against L. innocua ATCC 33090 and E. coli ATCC 11303, while clove oil showed MIC values of $0.125 \mathrm{ml} / 100 \mathrm{ml}$ against both strains tested in TSB medium using a broth microdilution method (data not shown). Burt and Reinders (2003) reported similar MIC values $(0.0625 \mathrm{ml} / 100 \mathrm{ml})$ for oregano oil against $E$. coli, while clove oil displayed bacteriostatic properties against $E$. coli at $0.25 \mathrm{ml} / 100 \mathrm{ml}$ (Moreira et al., 2005).

\subsection{Antimicrobial Effects of Oregano and Clove Essential Oils in a Reduced Salt Vegetable Soup}

Data obtained in this study indicated that the antimicrobial activity of EOs was considerably reduced in an actual commercial food product (Figure 1). Oregano and clove EOs did not display any antimicrobial properties in soup when used at their respective MICs $(\mathrm{P}>0.05)$, and a 32-fold increase in concentration of both oils was required to maintain the bacterial strains at their initial inoculation level (Figure 1). Although some studies have reported successful or potential application of essential oils as antimicrobial agents in food products such as fish $(0.05 \%$ v/v oregano and thyme oil) (Harpaz, Glatman, Drabkin, \& Gelman, 2003), chicken meat (1-2\% v/w clove oil) (Mytle, Anderson, Doyle, \& Smith, 2006), cheese (0.5 - 1\% v/w clove oil) (Menon \& Garg, 2001), in most cases the activity of plant derived antimicrobials was considerably reduced in food systems compared with broth media. For example, Smith-Palmer, Stewart and Fyfe (1998) reported that EOs of clove, cinnamon and thyme were effective against L. monocytogenes in TSB with MICs of $0.03-0.075 \%$. However, when subsequently evaluated for their activity in cheese, a $1 \%$ concentration of the oils was required to inhibit growth of $L$. monocytogenes (Smith-Palmer, Stewart, \& Fyfe, 2001). Overall, the data in this study would also indicate the necessity for significantly elevated levels of EO to be added for antimicrobial activity in food systems. 
A

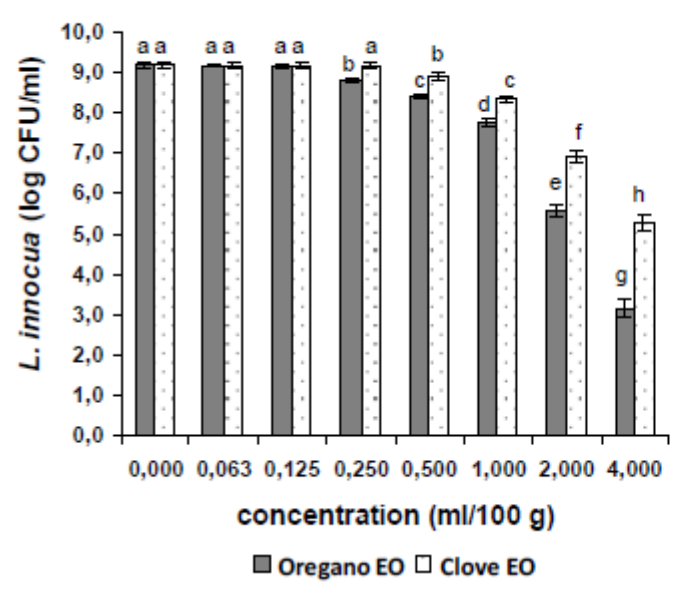

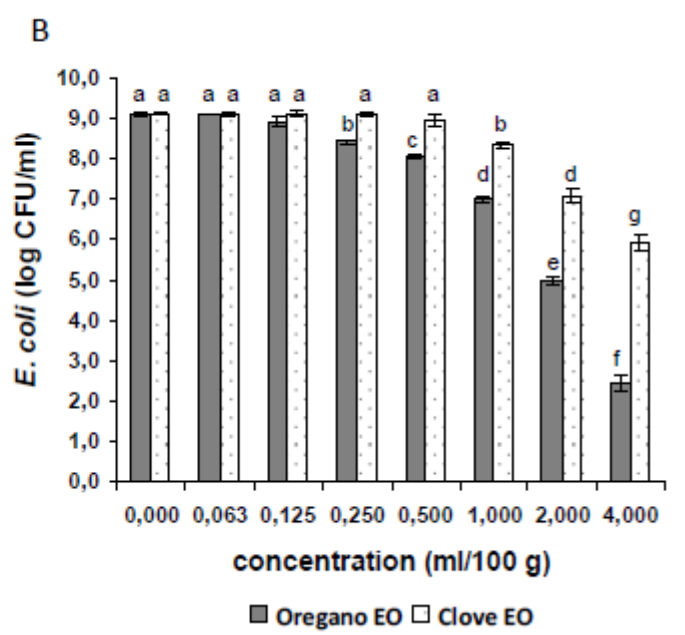

Figure 1. Effect of oregano and clove essential oils on survival of (A) L. innocua ATCC 33090 or (B) Escherichia coli ATCC 11303 in vegetable soup at $25^{\circ} \mathrm{C}$. Error bars indicate S. D. Different letters signify statistical differences between values $(\mathrm{P}<0.05)$

\subsection{Effects of Food Components, and Chemical Parameters on Antimicrobial Activity of Essential Oils}

As most foods consist mainly of carbohydrates, proteins, fats, salt, and water it is important to determine effect of these components on the antimicrobial properties of any proposed preparation for successful application in actual food systems (Devlieghere et al., 2004). Generally, antimicrobial activity of oregano and clove EOs, present in medium at $2 \times \mathrm{MIC}$ and MIC levels was reduced $(\mathrm{P}<0.05)$ when proteins were included in the growth medium at levels $\geq 1 \mathrm{~g} / 100 \mathrm{ml}$ (Table 1). At a protein concentration of $5 \mathrm{~g} / 100 \mathrm{ml}$ populations of $L$. innocua or $E$. coli treated with oregano oil at MIC, increased by 2.32 or $1.85 \log \mathrm{CFU} / \mathrm{ml}$, respectively compared with samples containing EO only. In the case of clove oil, populations of L. innocua or E. coli increased by 1.94 or $1.33 \log$ $\mathrm{CFU} / \mathrm{ml}$ respectively, indicating a possible antagonistic effect of added protein or a species related response to the added protein content (Table 1). Reduced antimicrobial effectiveness of added EO in presence of proteins may be attributed to complexing by hydrogen bonds between phenolic groups and peptides, and by hydrophobic interaction (Spencer et al., 1988). However, Gutierrez, Barry-Ryan and Bourke (2008) reported that the efficacy of oregano and thyme oils was enhanced in a medium containing proteins. These researchers used beef extract as a protein source, which consists mainly of peptones, amino acids and gelatin, while the WPC used in the present study consists mainly of $\beta$-lactoglobulin and $\alpha$-lactalbumin. Therefore, it is possible that differing nitrogenous compounds may influence the antimicrobial activity of phenolic constituents differently, as phenolics-protein complexation appears to depend strongly on the type of protein involved (Juven, Kanner, Schved, \& Weisslowicz, 1994). 
Table 1. Effect of added protein concentration on the antimicrobial efficacy of oregano and clove essential oils against Listeria innocua or Escherichia coli incubated at $37{ }^{\circ} \mathrm{C}$ for $24 \mathrm{~h}$ in TSB medium assessed at three EOs concentrations: MIC, $2 \times \mathrm{MIC}, 0.5 \times \mathrm{MIC}$

\begin{tabular}{|c|c|c|c|c|c|c|c|}
\hline \multirow{2}{*}{$\begin{array}{l}\text { Protein } \\
(\mathrm{g} / 100 \mathrm{ml})\end{array}$} & \multicolumn{3}{|c|}{ Oregano oil } & \multicolumn{3}{|c|}{ Clove oil } & \multirow{2}{*}{ Untreated } \\
\hline & $2 \times \mathrm{MIC}$ & $\mathrm{MIC}^{\mathrm{C}}$ & $0.5 \times \mathrm{MIC}$ & $2 \times \mathrm{MIC}$ & $\mathrm{MIC}^{\mathrm{C}}$ & $0.5 \times \mathrm{MIC}$ & \\
\hline \multicolumn{8}{|c|}{ Listeria innocua $(\log \mathrm{CFU} / \mathrm{ml})^{\mathrm{A}}$} \\
\hline 0 & $3.55 \pm 0.12^{\mathrm{a}}$ & $6.50 \pm 0.12^{\mathrm{a}}$ & $8.72 \pm 0.16^{\mathrm{a}}$ & $0.00^{\mathrm{a}, \mathrm{B}}$ & $6.98 \pm 0.13^{\mathrm{a}}$ & $8.48 \pm 0.19^{\mathrm{a}}$ & $9.20 \pm 0.10^{\mathrm{a}}$ \\
\hline 1 & $6.42 \pm 0.24^{\mathrm{b}}$ & $8.16 \pm 0.11^{\mathrm{b}}$ & $8.84 \pm 0.06^{\mathrm{ab}}$ & $1.06 \pm 0.71^{\mathrm{b}}$ & $8.32 \pm 0.27^{\mathrm{b}}$ & $8.88 \pm 0.26^{\mathrm{b}}$ & $9.04 \pm 0.08^{\mathrm{a}}$ \\
\hline 3 & $7.10 \pm 0.10^{\mathrm{c}}$ & $8.85 \pm 0.18^{c}$ & $8.98 \pm 0.08^{\mathrm{b}}$ & $1.95 \pm 0.28^{\mathrm{c}}$ & $8.85 \pm 0.25^{\mathrm{c}}$ & $8.98 \pm 0.12^{\mathrm{b}}$ & $8.98 \pm 0.11^{\mathrm{a}}$ \\
\hline 5 & $7.41 \pm 0.17^{\mathrm{d}}$ & $8.82 \pm 0.22^{\mathrm{c}}$ & $8.97 \pm 0.12^{\mathrm{b}}$ & $3.20 \pm 0.20^{\mathrm{d}}$ & $8.92 \pm 0.18^{\mathrm{c}}$ & $8.99 \pm 0.21^{\mathrm{b}}$ & $9.01 \pm 0.21^{\mathrm{a}}$ \\
\hline \multicolumn{8}{|c|}{ Escherichia coli $(\log \mathrm{CFU} / \mathrm{ml})^{\mathrm{A}}$} \\
\hline 0 & $0.00^{\mathrm{a}, \mathrm{B}}$ & $6.18 \pm 0.12^{\mathrm{a}}$ & $8.20 \pm 0.15^{\mathrm{a}}$ & $0.00^{\mathrm{a}, \mathrm{B}}$ & $7.11 \pm 0.16^{\mathrm{a}}$ & $8.01 \pm 0.16^{\mathrm{a}}$ & $9.14 \pm 0.11^{\mathrm{a}}$ \\
\hline 1 & $0.00^{\mathrm{a}, \mathrm{B}}$ & $6.51 \pm 0.17^{\mathrm{b}}$ & $8.47 \pm 0.14^{\mathrm{a}}$ & $1.34 \pm 0.38^{\mathrm{b}}$ & $7.78 \pm 0.23^{\mathrm{b}}$ & $8.19 \pm 0.22^{\mathrm{a}}$ & $9.15 \pm 0.09^{\mathrm{a}}$ \\
\hline 3 & $1.23 \pm 0.27^{\mathrm{b}}$ & $7.75 \pm 0.20^{\mathrm{c}}$ & $8.92 \pm 0.12^{\mathrm{b}}$ & $1.85 \pm 0.23^{\mathrm{c}}$ & $8.26 \pm 0.20^{\mathrm{c}}$ & $9.14 \pm 0.20^{\mathrm{b}}$ & $9.21 \pm 0.14^{\mathrm{a}}$ \\
\hline 5 & $1.99 \pm 0.31^{\mathrm{c}}$ & $8.03 \pm 0.17^{\mathrm{c}}$ & $9.08 \pm 0.12^{\mathrm{b}}$ & $2.30 \pm 0.21^{\mathrm{d}}$ & $8.44 \pm 0.19^{\mathrm{c}}$ & $9.15 \pm 0.28^{\mathrm{b}}$ & $9.15 \pm 0.09^{\mathrm{a}}$ \\
\hline
\end{tabular}

Antimicrobial activity of oregano and clove EOs was strongly decreased in presence of rapeseed oil (Table 2). Significantly higher levels $(\mathrm{P}<0.05)$ of viable bacteria were enumerated even at the lowest level of added rapeseed oil irrespective of concentration of EO. Populations of $L$. innocua or E. coli treated with clove oil at $2 \times M I C$ in presence of $1 \mathrm{ml} / 100 \mathrm{ml}$ of rapeseed oil were detected at levels of 4.21 or $4.96 \log \mathrm{CFU} / \mathrm{ml}$, respectively. In contrast, in the absence of rapeseed oil, surviving viable bacteria could not be detected, indicating a possible antagonistic effect of fat on the efficacy of EOs. These trends were also found for addition of sunflower oil (data not shown), demonstrating strong protective effects of vegetable oils towards bacterial cells when treated with EOs. Smith-Palmer, Stewart and Fyfe (2001) observed that the efficiency of plant EOs against $L$. monocytogenes in high-fat soft cheese was significantly reduced compared with activity in low-fat cheese. Partitioning of essential oil components into the lipid phase of the foods has been suggested as an explanation for reduced activity in food products. It is generally thought that if the hydrophobic components of essential oils are highly absorbed onto a fatty fraction of food, there will be relatively less EO available to act against bacteria growing in the aqueous phase (Mejlholm \& Dalgaard, 2002). 
Table 2. Effect of added fat concentration on the antimicrobial efficacy of oregano and clove essential oils against Listeria innocua or Escherichia coli incubated at $37{ }^{\circ} \mathrm{C}$ for $24 \mathrm{~h}$ in TSB medium assessed at three EOs concentrations: MIC, $2 \times \mathrm{MIC}, 0.5 \times \mathrm{MIC}$

\begin{tabular}{|c|c|c|c|c|c|c|c|}
\hline \multirow{2}{*}{$\begin{array}{l}\text { Fat } \\
(\mathrm{ml} / 100 \mathrm{ml})\end{array}$} & \multicolumn{3}{|c|}{ Oregano oil } & \multicolumn{3}{|c|}{ Clove oil } & \multirow{2}{*}{ Untreated } \\
\hline & $2 \times \mathrm{MIC}$ & $\mathrm{MIC}^{\mathrm{C}}$ & $0.5 \times \mathrm{MIC}$ & $2 \times \mathrm{MIC}$ & $\mathrm{MIC}^{\mathrm{C}}$ & $0.5 \times \mathrm{MIC}$ & \\
\hline \multicolumn{8}{|c|}{ Listeria innocua $(\log \mathrm{CFU} / \mathrm{ml})^{\mathrm{A}}$} \\
\hline 0 & $3.55 \pm 0.12^{\mathrm{a}}$ & $6.50 \pm 0.12^{\mathrm{a}}$ & $8.72 \pm 0.16^{\mathrm{a}}$ & $0.00^{\mathrm{a}, \mathrm{B}}$ & $6.98 \pm 0.13^{\mathrm{a}}$ & $8.48 \pm 0.19^{\mathrm{a}}$ & $9.20 \pm 0.10^{\mathrm{a}}$ \\
\hline 1 & $6.00 \pm 0.22^{\mathrm{b}}$ & $8.45 \pm 0.14^{\mathrm{b}}$ & $9.04 \pm 0.18^{\mathrm{b}}$ & $3.91 \pm 0.48^{\mathrm{b}}$ & $8.67 \pm 0.18^{b}$ & $9.08 \pm 0.16^{\mathrm{b}}$ & $9.18 \pm 0.09^{\mathrm{a}}$ \\
\hline 5 & $9.09 \pm 0.11^{\mathrm{c}}$ & $9.20 \pm 0.11^{\mathrm{c}}$ & $9.21 \pm 0.08^{\mathrm{c}}$ & $7.30 \pm 0.22^{\mathrm{c}}$ & $9.14 \pm 0.21^{\mathrm{c}}$ & $9.22 \pm 0.11^{\mathrm{c}}$ & $9.20 \pm 0.11^{\mathrm{a}}$ \\
\hline 10 & $9.20 \pm 0.08^{\mathrm{cd}}$ & $9.18 \pm 0.09^{\mathrm{c}}$ & $9.23 \pm 0.07^{\mathrm{c}}$ & $9.08 \pm 0.16^{\mathrm{d}}$ & $9.20 \pm 0.09^{\mathrm{c}}$ & $9.20 \pm 0.12^{\mathrm{c}}$ & $9.24 \pm 0.12^{\mathrm{a}}$ \\
\hline 30 & $9.23 \pm 0.08^{\mathrm{d}}$ & $9.20 \pm 0.07^{\mathrm{c}}$ & $9.21 \pm 0.12^{\mathrm{c}}$ & $9.11 \pm 0.16^{\mathrm{d}}$ & $9.23 \pm 0.11^{\mathrm{c}}$ & $9.19 \pm 0.15^{\mathrm{c}}$ & $9.21 \pm 0.12^{\mathrm{a}}$ \\
\hline \multicolumn{8}{|c|}{ Escherichia coli $(\log \mathrm{CFU} / \mathrm{ml})^{\mathrm{A}}$} \\
\hline 0 & $0.00^{\mathrm{a}, \mathrm{B}}$ & $6.19 \pm 0.14^{\mathrm{a}}$ & $8.21 \pm 0.16^{\mathrm{a}}$ & $0.00^{\mathrm{a}, \mathrm{B}}$ & $7.10 \pm 0.15^{\mathrm{a}}$ & $8.01 \pm 0.16^{\mathrm{a}}$ & $9.11 \pm 0.11^{\mathrm{a}}$ \\
\hline 1 & $4.21 \pm 0.33^{\mathrm{b}}$ & $7.38 \pm 0.21^{\mathrm{b}}$ & $8.94 \pm 0.19^{b}$ & $4.96 \pm 0.52^{\mathrm{b}}$ & $8.23 \pm 0.16^{\mathrm{b}}$ & $9.07 \pm 0.20^{\mathrm{b}}$ & $9.10 \pm 0.09^{\mathrm{a}}$ \\
\hline 5 & $8.25 \pm 0.26^{\mathrm{c}}$ & $9.11 \pm 0.11^{\mathrm{c}}$ & $9.09 \pm 0.21^{\mathrm{b}}$ & $7.60 \pm 0.31^{\mathrm{c}}$ & $9.09 \pm 0.22^{\mathrm{c}}$ & $9.10 \pm 0.24^{\mathrm{b}}$ & $9.08 \pm 0.14^{\mathrm{a}}$ \\
\hline 10 & $8.82 \pm 0.19^{d}$ & $9.14 \pm 0.06^{\mathrm{c}}$ & $9.12 \pm 0.11^{\mathrm{b}}$ & $8.94 \pm 0.18^{\mathrm{d}}$ & $9.13 \pm 0.09^{c}$ & $9.11 \pm 0.18^{\mathrm{b}}$ & $9.12 \pm 0.09^{\mathrm{a}}$ \\
\hline 30 & $9.03 \pm 0.24^{\mathrm{e}}$ & $9.11 \pm 0.07^{\mathrm{c}}$ & $9.10 \pm 0.09^{b}$ & $8.96 \pm 0.16^{\mathrm{d}}$ & $9.12 \pm 0.08^{c}$ & $9.09 \pm 0.12^{\mathrm{b}}$ & $9.10 \pm 0.14^{\mathrm{a}}$ \\
\hline
\end{tabular}

${ }^{\mathrm{a}-\mathrm{e}}$ Means in the same column for each strain followed by different superscript letters (a-e) differ significantly (P $<0.05)$.

${ }^{\text {A }}$ Results are expressed as $\log \mathrm{CFU} / \mathrm{ml}(\mathrm{mean} \pm \mathrm{SD})$.

${ }^{\mathrm{B}}$ Less than minimum level of sensitivity of assay procedure $(10 \mathrm{CFU} / \mathrm{ml})$.

${ }^{\text {C }}$ MICs of oregano EO against L. innocua ATCC 33090 and E. coli ATCC 11303: $0.0625 \mathrm{ml} / 100 \mathrm{ml}$, MICs of clove EO against L. innocua ATCC 33090 and E. coli ATCC 11303: $0.125 \mathrm{ml} / 100 \mathrm{ml}$.

Addition of $\mathrm{NaCl}$ at concentration of $0.1 \mathrm{~g} / 100 \mathrm{ml}$ to growth medium with added $\mathrm{EO}$, had no influence on the efficacy of essential oils $(\mathrm{P}>0.05)$ (Table 3$)$. However, the bacterial counts were progressively reduced $(\mathrm{P}<0.05)$ with a further increase in $\mathrm{NaCl}$ concentration, with respect to samples with $\mathrm{EOs}$ only. When $\mathrm{NaCl}$ was added at a concentration of $5 \mathrm{~g} / 100 \mathrm{ml}$ to bacterial suspensions treated with any of EOs at respective MICs, bacterial counts were reduced below the detection limit, indicating a positive influence of salt on antimicrobial activity of herb and spice derived preparations (Table 3). Control populations without EOs were quite resistant to the action of $\mathrm{NaCl}$ alone, as L. innocua and $E$. coli were present at levels of 8.48 and $7.72 \log \mathrm{CFU} / \mathrm{ml}$ respectively, when grown in TSB with $5 \mathrm{~g} / 100 \mathrm{ml} \mathrm{NaCl}$ added (Table 3). Wendakoon and Sakaguchi (1993) proposed a mechanism for synergism between sodium chloride and clove that involves an increase in cell membrane permeability, and subsequently growth inhibition due to $\mathrm{NaCl}$ action on intracellular enzymes. 
Table 3. Effect of added $\mathrm{NaCl}$ concentration on the antimicrobial efficacy of oregano and clove essential oils against Listeria innocua or Escherichia coli incubated at $37^{\circ} \mathrm{C}$ for $24 \mathrm{~h}$ in TSB medium assessed at three EO concentrations: MIC, $2 \times$ MIC, $0.5 \times \mathrm{MIC}$

\begin{tabular}{|c|c|c|c|c|c|c|c|}
\hline \multirow{2}{*}{$\begin{array}{l}\mathrm{NaCl} \\
(\mathrm{g} / 100 \mathrm{ml})\end{array}$} & \multicolumn{3}{|c|}{ Oregano oil } & \multicolumn{3}{|c|}{ Clove oil } & \multirow{2}{*}{ Untreated } \\
\hline & $2 \times \mathrm{MIC}$ & $\mathrm{MIC}^{\mathrm{C}}$ & $0.5 \times \mathrm{MIC}$ & $2 \times \mathrm{MIC}$ & $\mathrm{MIC}^{\mathrm{C}}$ & $0.5 \times \mathrm{MIC}$ & \\
\hline \multicolumn{8}{|c|}{ Listeria innocua $(\log \mathrm{CFU} / \mathrm{ml})^{\mathrm{A}}$} \\
\hline 0 & $3.55 \pm 0.12^{\mathrm{a}}$ & $6.50 \pm 0.12^{\mathrm{a}}$ & $8.72 \pm 0.16^{\mathrm{a}}$ & $0.00^{\mathrm{B}}$ & $6.98 \pm 0.13^{\mathrm{a}}$ & $8.48 \pm 0.19^{\mathrm{a}}$ & $9.20 \pm 0.10^{\mathrm{a}}$ \\
\hline 0.1 & $3.60 \pm 0.21^{\mathrm{a}}$ & $6.53 \pm 0.16^{\mathrm{a}}$ & $8.73 \pm 0.19^{\mathrm{a}}$ & $0.00^{\mathrm{B}}$ & $6.94 \pm 0.29^{\mathrm{a}}$ & $8.50 \pm 0.19^{\mathrm{a}}$ & $9.20 \pm 0.09^{\mathrm{a}}$ \\
\hline 0.5 & $2.96 \pm 0.36^{\mathrm{b}}$ & $5.68 \pm 0.19^{b}$ & $8.34 \pm 0.14^{\mathrm{b}}$ & $0.00^{\mathrm{B}}$ & $5.72 \pm 0.22^{\mathrm{b}}$ & $8.00 \pm 0.21^{\mathrm{b}}$ & $9.07 \pm 0.14^{\mathrm{ab}}$ \\
\hline 1 & $0.00^{\mathrm{c}, \mathrm{B}}$ & $2.08 \pm 0.48^{\mathrm{c}}$ & $7.11 \pm 0.11^{\mathrm{c}}$ & $0.00^{\mathrm{B}}$ & $0.00^{\mathrm{c}, \mathrm{B}}$ & $7.23 \pm 0.27^{\mathrm{c}}$ & $9.01 \pm 0.16^{\mathrm{ab}}$ \\
\hline 3 & $0.00^{\mathrm{c}, \mathrm{B}}$ & $0.00^{\mathrm{d}, \mathrm{B}}$ & $6.12 \pm 0.18^{\mathrm{d}}$ & $0.00^{\mathrm{B}}$ & $0.00^{\mathrm{c}, \mathrm{B}}$ & $6.15 \pm 0.24^{\mathrm{d}}$ & $8.90 \pm 0.11^{\mathrm{b}}$ \\
\hline 5 & $0.00^{\mathrm{c}, \mathrm{B}}$ & $0.00^{\mathrm{d}, \mathrm{B}}$ & $5.01 \pm 0.17^{\mathrm{e}}$ & $0.00^{\mathrm{B}}$ & $0.00^{\mathrm{c}, \mathrm{B}}$ & $4.91 \pm 0.29^{\mathrm{e}}$ & $8.48 \pm 0.18^{\mathrm{c}}$ \\
\hline \multicolumn{8}{|c|}{ Escherichia coli $(\log \mathrm{CFU} / \mathrm{ml})^{\mathrm{A}}$} \\
\hline 0 & $0.00^{\mathrm{B}}$ & $6.18 \pm 0.14^{\mathrm{a}}$ & $8.20 \pm 0.16^{\mathrm{a}}$ & $0.00^{\mathrm{B}}$ & $7.11 \pm 0.15^{\mathrm{a}}$ & $8.01 \pm 0.16^{\mathrm{a}}$ & $9.11 \pm 0.11^{\mathrm{a}}$ \\
\hline 0.1 & $0.00^{\mathrm{B}}$ & $6.21 \pm 0.28^{\mathrm{a}}$ & $8.19 \pm 0.23^{\mathrm{a}}$ & $0.00^{\mathrm{B}}$ & $7.19 \pm 0.21^{\mathrm{a}}$ & $7.98 \pm 0.21^{\mathrm{a}}$ & $9.12 \pm 0.08^{\mathrm{a}}$ \\
\hline 0.5 & $0.00^{\mathrm{B}}$ & $6.00 \pm 0.25^{\mathrm{a}}$ & $8.03 \pm 0.41^{b}$ & $0.00^{\mathrm{B}}$ & $7.25 \pm 0.27^{\mathrm{a}}$ & $7.68 \pm 0.16^{\mathrm{ab}}$ & $9.08 \pm 0.07^{\mathrm{a}}$ \\
\hline 1 & $0.00^{\mathrm{B}}$ & $5.39 \pm 0.19^{b}$ & $7.67 \pm 0.20^{\mathrm{c}}$ & $0.00^{\mathrm{B}}$ & $6.60 \pm 0.31^{\mathrm{b}}$ & $7.40 \pm 0.28^{\mathrm{b}}$ & $8.64 \pm 0.15^{\mathrm{b}}$ \\
\hline 3 & $0.00^{\mathrm{B}}$ & $4.83 \pm 0.23^{\mathrm{c}}$ & $6.45 \pm 0.20^{\mathrm{d}}$ & $0.00^{\mathrm{B}}$ & $6.05 \pm 0.20^{\mathrm{c}}$ & $6.78 \pm 0.17^{\mathrm{c}}$ & $8.21 \pm 0.19^{c}$ \\
\hline 5 & $0.00^{\mathrm{B}}$ & $0.00^{\mathrm{d}, \mathrm{B}}$ & $2.83 \pm 0.56^{\mathrm{e}}$ & $0.00^{\mathrm{B}}$ & $0.00^{\mathrm{d}, \mathrm{B}}$ & $3.13 \pm 0.29^{\mathrm{d}}$ & $7.72 \pm 0.19^{\mathrm{d}}$ \\
\hline
\end{tabular}

${ }^{\mathrm{a}-\mathrm{e}}$ Means in the same column for each strain followed by different superscript letters (a-e) differ significantly (P $<0.05)$

${ }^{\mathrm{A}}$ Results are expressed as $\log \mathrm{CFU} / \mathrm{ml}(\mathrm{mean} \pm \mathrm{SD})$

${ }^{\mathrm{B}}$ Less than minimum level of sensitivity of assay procedure $(10 \mathrm{CFU} / \mathrm{ml})$.

${ }^{\mathrm{C}}$ MICs of oregano EO against L. innocua ATCC 33090 and E. coli ATCC 11303: $0.0625 \mathrm{ml} / 100 \mathrm{ml}$, MICs of clove EO against L. innocua ATCC 33090 and E. coli ATCC 11303: 0.125 ml/100 ml.

Addition of water soluble starch at concentration of $1 \mathrm{~g} / 100 \mathrm{ml}$ to growth medium with added EOs had no influence on antimicrobial efficacy $(\mathrm{P}>0.05)$ (Table 4). However, bacterial counts were significantly higher $(\mathrm{P}<$ 0.05) with a further increase in starch concentration, with respect to samples with EOs only. At a starch concentration of $20 \mathrm{~g} / 100 \mathrm{ml}$, counts of L. innocua or E. coli treated with oregano or clove oil at respective MICs, increased on average by approx. $1 \log \mathrm{CFU} / \mathrm{ml}$, compared with samples containing EOs only $(\mathrm{P}<0.05)$, indicating a degree of inhibition by water soluble starch on the efficacy of the EOs (Table 4). Previously, it was observed that the growth rate of L. monocytogenes treated with EOs decreased at high starch concentrations (Gutierrez et al., 2008). Devlieghere et al. (2004) also reported a negative effect of carbohydrates on antimicrobial properties of chitosan in the presence of a high level $(30 \mathrm{~g} / 100 \mathrm{ml})$ of starch. It should be noted however, that various types and grades of carbohydrates and starches are available for use in the food industry, which may also influence their interactions with EOs. 
Table 4. Effect of added water soluble starch concentration on the antimicrobial efficacy of oregano and clove essential oils against Listeria innocua and Escherichia coli incubated at $37^{\circ} \mathrm{C}$ for $24 \mathrm{~h}$ in TSB medium assessed at three EOs concentrations: MIC, $2 \times \mathrm{MIC}, 0.5 \times \mathrm{MIC}$

\begin{tabular}{|c|c|c|c|c|c|c|c|}
\hline \multirow{2}{*}{$\begin{array}{l}\text { Starch } \\
(\mathrm{g} / 100 \mathrm{ml})\end{array}$} & \multicolumn{3}{|c|}{ Oregano oil } & \multicolumn{3}{|c|}{ Clove oil } & \multirow{2}{*}{ Untreated } \\
\hline & $2 \times \mathrm{MIC}$ & $\mathrm{MIC}^{\mathrm{C}}$ & $0.5 \times \mathrm{MIC}$ & $2 \times \mathrm{MIC}$ & $\mathrm{MIC}^{\mathrm{C}}$ & $0.5 \times \mathrm{MIC}$ & \\
\hline \multicolumn{8}{|c|}{ Listeria innocua $(\log \mathrm{CFU} / \mathrm{ml})^{\mathrm{A}}$} \\
\hline 0 & $3.55 \pm 0.12^{\mathrm{a}}$ & $6.50 \pm 0.12^{\mathrm{a}}$ & $8.72 \pm 0.16^{\mathrm{a}}$ & $0.00^{\mathrm{B}}$ & $6.96 \pm 0.12^{\mathrm{a}}$ & $8.48 \pm 0.19^{\mathrm{a}}$ & $9.22 \pm 0.10^{\mathrm{a}}$ \\
\hline 1 & $3.59 \pm 0.20^{\mathrm{a}}$ & $6.58 \pm 0.19^{\mathrm{ab}}$ & $8.74 \pm 0.22^{\mathrm{a}}$ & $0.00^{\mathrm{B}}$ & $7.00 \pm 0.19^{\mathrm{a}}$ & $8.54 \pm 0.23^{\mathrm{a}}$ & $9.23 \pm 0.09^{\mathrm{a}}$ \\
\hline 5 & $3.71 \pm 0.23^{\mathrm{a}}$ & $6.99 \pm 0.21^{\mathrm{bc}}$ & $8.86 \pm 0.20^{\mathrm{a}}$ & $0.00^{\mathrm{B}}$ & $7.15 \pm 0.19^{\mathrm{a}}$ & $8.86 \pm 0.12^{\mathrm{ab}}$ & $9.21 \pm 0.11^{\mathrm{a}}$ \\
\hline 10 & $4.28 \pm 0.18^{\mathrm{b}}$ & $7.29 \pm 0.08^{\mathrm{cd}}$ & $8.99 \pm 0.06^{\mathrm{a}}$ & $0.00^{\mathrm{B}}$ & $7.73 \pm 0.13^{\mathrm{b}}$ & $9.02 \pm 0.14^{\mathrm{b}}$ & $9.19 \pm 0.14^{\mathrm{a}}$ \\
\hline 20 & $4.62 \pm 0.30^{\mathrm{b}}$ & $7.53 \pm 0.11^{\mathrm{d}}$ & $9.04 \pm 0.11^{\mathrm{a}}$ & $0.00^{\mathrm{B}}$ & $8.04 \pm 0.15^{\mathrm{b}}$ & $9.03 \pm 0.18^{\mathrm{b}}$ & $9.20 \pm 0.10^{\mathrm{a}}$ \\
\hline \multicolumn{8}{|c|}{ Escherichia coli $(\log \mathrm{CFU} / \mathrm{ml})^{\mathrm{A}}$} \\
\hline 0 & $0.00^{\mathrm{B}}$ & $6.18 \pm 0.14^{\mathrm{a}}$ & $8.20 \pm 0.15^{\mathrm{a}}$ & $0.00^{\mathrm{B}}$ & $7.11 \pm 0.15^{\mathrm{a}}$ & $8.01 \pm 0.16^{\mathrm{a}}$ & $9.12 \pm 0.11^{\mathrm{a}}$ \\
\hline 1 & $0.00^{\mathrm{B}}$ & $6.26 \pm 0.17^{\mathrm{a}}$ & $8.28 \pm 0.26^{\mathrm{ab}}$ & $0.00^{\mathrm{B}}$ & $7.18 \pm 0.21^{\mathrm{a}}$ & $8.08 \pm 0.21^{\mathrm{a}}$ & $9.11 \pm 0.10^{\mathrm{a}}$ \\
\hline 5 & $0.00^{\mathrm{B}}$ & $6.49 \pm 0.15^{\mathrm{ab}}$ & $8.72 \pm 0.28^{b c}$ & $0.00^{\mathrm{B}}$ & $7.49 \pm 0.15^{\mathrm{a}}$ & $8.26 \pm 0.12^{\mathrm{a}}$ & $9.08 \pm 0.21^{\mathrm{a}}$ \\
\hline 10 & $0.00^{\mathrm{B}}$ & $6.82 \pm 0.10^{\mathrm{bc}}$ & $8.96 \pm 0.14^{\mathrm{c}}$ & $0.00^{\mathrm{B}}$ & $7.89 \pm 0.23^{b}$ & $8.71 \pm 0.21^{\mathrm{b}}$ & $9.11 \pm 0.06^{\mathrm{a}}$ \\
\hline 20 & $0.00^{\mathrm{b}}$ & $7.09 \pm 0.10^{\mathrm{c}}$ & $8.94 \pm 0.13^{\mathrm{c}}$ & $0.00^{\mathrm{B}}$ & $8.11 \pm 0.10^{b}$ & $8.87 \pm 0.28^{\mathrm{b}}$ & $9.14 \pm 0.09^{\mathrm{a}}$ \\
\hline
\end{tabular}

${ }^{\mathrm{a}-\mathrm{d}}$ Means in the same column for each strain followed by different superscript letters (a-d) differ significantly (P $<0.05)$.

${ }^{\text {A }}$ Results are expressed as $\log \mathrm{CFU} / \mathrm{ml}(\mathrm{mean} \pm \mathrm{SD})$.

${ }^{\mathrm{B}}$ Less than minimum level of sensitivity of assay procedure $(10 \mathrm{CFU} / \mathrm{ml})$.

${ }^{\text {C }}$ MICs of oregano EO against L. innocua ATCC 33090 and E. coli ATCC 11303: $0.0625 \mathrm{ml} / 100 \mathrm{ml}$, MICs of clove EO against $L$. innocua ATCC 33090 and E. coli ATCC 11303: $0.125 \mathrm{ml} / 100 \mathrm{ml}$.

Regarding the effect of water activity $\left(\mathrm{a}_{\mathrm{w}}\right)$ on the efficacy of EOs, data obtained for clove and oregano oils followed similar trends, therefore, results for clove oil only are described and illustrated in Figure 2. To differentiate between the effect of $\mathrm{a}_{\mathrm{w}}$ and the nature of the solute controlling the $\mathrm{a}_{\mathrm{w}}, \mathrm{NaCl}$, sucrose or glycerol were used separately to adjust this parameter. Generally, for each of the solutes used, lowering of $\mathrm{a}_{\mathrm{w}}$ resulted in enhanced antimicrobial activity of clove EO (Figure 2 A-F). However, depending on the type or concentration of solute used to adjust $a_{w}$, the efficacy of clove oil varied considerably, even at the same $a_{w}$. For example, populations of $L$. innocua or $E$. coli treated with clove oil at MIC, were completely inactivated at an $\mathrm{a}_{\mathrm{w}}$ of 0.975 adjusted with $\mathrm{NaCl}$ (Figure $2 \mathrm{~A}, \mathrm{D}$ ). However, when $\mathrm{a}_{\mathrm{w}}$ was adjusted using sucrose or glycerol, cell counts were detected at levels of 6.2 or $7.0 \log \mathrm{CFU} / \mathrm{ml}$, respectively for L. innocua (Figure $2 \mathrm{~B}, \mathrm{C}$ ), and at levels of 3.96 or $7.01 \log \mathrm{CFU} / \mathrm{ml}$, respectively for $E$. coli (Figure $2 \mathrm{E}, \mathrm{F}$ ). Further decreasing of $\mathrm{a}_{\mathrm{w}}$ to 0.950 using sucrose resulted in a complete inactivation of both bacteria treated with clove oil (Figure $2 \mathrm{~B}, \mathrm{E}$ ), whereas in presence of glycerol at the same $\mathrm{a}_{\mathrm{w}}, L$. innocua and E. coli were detected at levels of 6.5 and $3.01 \log \mathrm{CFU} / \mathrm{ml}$, respectively (Figure $2 \mathrm{E}, \mathrm{F}$ ). Therefore, results of this study indicate that the parameter "water activity" per se may not determine the antimicrobial efficacy of EOs. Instead, our data suggests that the nature of the $\mathrm{a}_{\mathrm{w}}$ controlling solute and its concentration in the suspending medium may considerably influence the antimicrobial activity of EOs (Garcia-Gonzalez et al., 2009). 

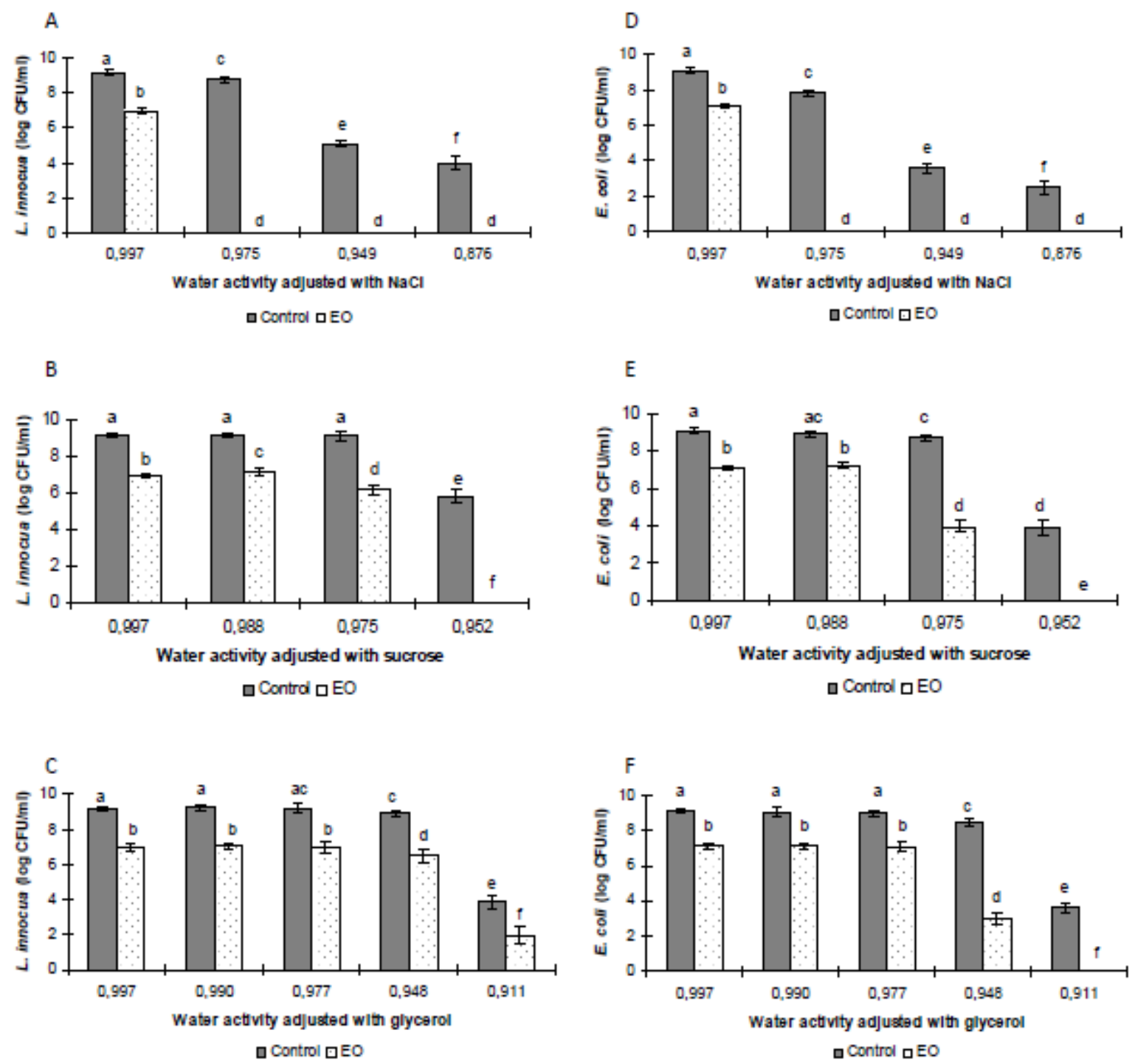

Figure 2. Effect of $\mathrm{a}_{\mathrm{w}}$ adjusted with $\mathrm{NaCl}(\mathrm{A}, \mathrm{D})$, sucrose (B, E), or glycerol (C, F) on growth of L. innocua ATCC 33090 (A, B, C) or Escherichia coli ATCC 11303 (D, E, F) in the presence of clove essential oil at MIC. Error bars indicate S. D. Error bars indicate S. D. Different letters signify statistical differences between values $(\mathrm{P}<0.05)$

The effect of $\mathrm{pH}$ on the antimicrobial activity of oregano and clove oils is shown in Table 5. Survival of either $L$. innocua or $E$. coli was not influenced by alterations in $\mathrm{pH}$ over the range 8.0 to $6.0(\mathrm{P}>0.05)$. However, further acidification of growth medium with $\mathrm{HCl}$ to 5.0 or 4.0 resulted in significantly reduced cell counts $(\mathrm{P}<0.05)$. This was especially evident at $\mathrm{pH} 4.0$, where in presence of oregano or clove EOs at respective MICs, survivors could not be detected for either of the bacterial strains, indicating synergistic antimicrobial effects of EOs on acidification of growth medium. Hsieh, Mau and Huang (2001) also noted enhanced antimicrobial activity of plant extracts and EOs at acidic $\mathrm{pH}$ values. This effect may be attributed either to the direct effect of $\mathrm{pH}$ or to an increase in the hydrophobicity of EOs and extracts of herbs and spices at low $\mathrm{pH}$ values. While these ingredients tend to partition in the lipid phase of the food, they can also dissolve more easily in the lipids of the cell membranes of bacteria and thereby display greater antimicrobial activity (Holley \& Patel, 2005). 
Table 5. Effect of $\mathrm{pH}$ variation on the antimicrobial efficacy of oregano and clove essential oils against Listeria innocua or Escherichia coli incubated at $37^{\circ} \mathrm{C}$ for $24 \mathrm{~h}$ in TSB medium assessed at three EOs concentrations: MIC, $2 \times$ MIC, $0.5 \times$ MIC

\begin{tabular}{|c|c|c|c|c|c|c|c|}
\hline \multirow{2}{*}{$\mathrm{pH}$} & \multicolumn{3}{|c|}{ Oregano oil } & \multicolumn{3}{|c|}{ Clove oil } & \multirow{2}{*}{ Untreated } \\
\hline & $2 \times \mathrm{MIC}$ & $\mathrm{MIC}^{\mathrm{C}}$ & $0.5 \times \mathrm{MIC}$ & $2 \times \mathrm{MIC}$ & $\mathrm{MIC}^{\mathrm{C}}$ & $0.5 \times \mathrm{MIC}$ & \\
\hline \multicolumn{8}{|c|}{ Listeria innocua $(\log \mathrm{CFU} / \mathrm{ml})^{\mathrm{A}}$} \\
\hline 8.0 & $3.50 \pm 0.17^{\mathrm{a}}$ & $6.49 \pm 0.15^{\mathrm{a}}$ & $8.81 \pm 0.17^{\mathrm{a}}$ & $0^{\mathrm{B}}$ & $6.99 \pm 0.16^{\mathrm{a}}$ & $8.50 \pm 0.11^{\mathrm{a}}$ & $9.26 \pm 0.14^{\mathrm{a}}$ \\
\hline 7.0 & $3.56 \pm 0.12^{\mathrm{a}}$ & $6.51 \pm 0.12^{\mathrm{a}}$ & $8.70 \pm 0.19^{\mathrm{ab}}$ & $0^{\mathrm{B}}$ & $7.01 \pm 0.25^{\mathrm{a}}$ & $8.52 \pm 0.20^{\mathrm{a}}$ & $9.21 \pm 0.14^{\mathrm{a}}$ \\
\hline 6.0 & $3.46 \pm 0.24^{\mathrm{a}}$ & $6.38 \pm 0.22^{\mathrm{a}}$ & $8.47 \pm 0.14^{\mathrm{b}}$ & $0^{\mathrm{B}}$ & $6.96 \pm 0.10^{\mathrm{a}}$ & $8.20 \pm 0.24^{\mathrm{a}}$ & $8.89 \pm 0.21^{\mathrm{b}}$ \\
\hline 5.0 & $2.78 \pm 0.37^{\mathrm{b}}$ & $5.92 \pm 0.22^{\mathrm{b}}$ & $6.44 \pm 0.21^{\mathrm{c}}$ & $0^{\mathrm{B}}$ & $6.23 \pm 0.13^{\mathrm{b}}$ & $6.59 \pm 0.18^{\mathrm{b}}$ & $8.23 \pm 0.14^{\mathrm{c}}$ \\
\hline 4.0 & $0^{\mathrm{c}, \mathrm{B}}$ & $0^{\mathrm{c}, \mathrm{B}}$ & $0^{\mathrm{d}, \mathrm{B}}$ & $0^{\mathrm{B}}$ & $0^{\mathrm{c}, \mathrm{B}}$ & $0^{\mathrm{c}, \mathrm{B}}$ & $4.65 \pm 0.23^{d}$ \\
\hline \multicolumn{8}{|c|}{ Escherichia coli $(\log \mathrm{CFU} / \mathrm{ml})^{\mathrm{A}}$} \\
\hline 8.0 & $0^{\mathrm{B}}$ & $6.14 \pm 0.07^{\mathrm{a}}$ & $8.14 \pm 0.12^{\mathrm{a}}$ & $0^{\mathrm{B}}$ & $7.08 \pm 0.18^{\mathrm{a}}$ & $7.68 \pm 0.20^{\mathrm{ab}}$ & $9.16 \pm 0.11^{\mathrm{a}}$ \\
\hline 7.0 & $0^{\mathrm{B}}$ & $6.20 \pm 0.13^{\mathrm{a}}$ & $8.23 \pm 0.19^{\mathrm{a}}$ & $0^{\mathrm{B}}$ & $7.19 \pm 0.10^{\mathrm{a}}$ & $7.90 \pm 0.19^{\mathrm{a}}$ & $9.12 \pm 0.08^{\mathrm{a}}$ \\
\hline 6.0 & $0^{\mathrm{B}}$ & $6.16 \pm 0.14^{\mathrm{a}}$ & $8.18 \pm 0.10^{\mathrm{a}}$ & $0^{\mathrm{B}}$ & $7.20 \pm 0.15^{\mathrm{a}}$ & $7.81 \pm 0.14^{\mathrm{a}}$ & $9.10 \pm 0.11^{\mathrm{a}}$ \\
\hline 5.0 & $0^{\mathrm{B}}$ & $5.34 \pm 0.28^{b}$ & $7.68 \pm 0.19^{\mathrm{b}}$ & $0^{\mathrm{B}}$ & $5.71 \pm 0.17^{\mathrm{b}}$ & $7.32 \pm 0.19^{\mathrm{b}}$ & $8.62 \pm 0.18^{b}$ \\
\hline 4.0 & $0^{\mathrm{B}}$ & $0^{\mathrm{c}, \mathrm{B}}$ & $2.68 \pm 0.23^{\mathrm{c}}$ & $0^{\mathrm{B}}$ & $0^{\mathrm{c}, \mathrm{B}}$ & $3.42 \pm 0.25^{\mathrm{c}}$ & $5.30 \pm 0.15^{\mathrm{c}}$ \\
\hline
\end{tabular}

${ }^{\mathrm{a}-\mathrm{d}}$ Means in the same column for each strain followed by different superscript letters (a-d) differ significantly (P $<0.05)$.

${ }^{\mathrm{A}}$ Results are expressed as $\log \mathrm{CFU} / \mathrm{ml}($ mean $\pm \mathrm{SD})$.

${ }^{\mathrm{B}}$ Less than minimum level of sensitivity of assay procedure (10 CFU/ml).

${ }^{\text {C }}$ MICs of oregano EO against L. innocua ATCC 33090 and E. coli ATCC 11303: $0.0625 \mathrm{ml} / 100 \mathrm{ml}$, MICs of clove EO against L. innocua ATCC 33090 and E. coli ATCC 11303: $0.125 \mathrm{ml} / 100 \mathrm{ml}$.

Acidity is commonly used to control microbial spoilage in foods. However, some studies indicate that the inhibitory effects of acidic $\mathrm{pH}$ depends on the particular acid used to adjust the medium (Buchanan, Golden, \& Whiting, 1993). Therefore, the efficacy of oregano and clove oils was evaluated at a constant $\mathrm{pH}$ (5.0) which was obtained using either strong inorganic $(\mathrm{HCl})$ or weak organic acids (citric, lactic, acetic acids). Results are presented in Figure 3. Acidification of growth medium with organic acids considerably enhanced the antimicrobial properties of EOs, as demonstrated by a significant $(\mathrm{P}<0.05)$ decrease in populations of $L$. innocua or $E$. coli treated with oregano or clove oil, in media acidified using organic acids compared with acidification using hydrochloric acid (Figure 3). Both EOs displayed bactericidal properties against $L$. innocua or $E$. coli when $\mathrm{pH}$ of the growth medium was adjusted with lactic and acetic acids, respectively. Bacterial growth in control samples without EOs also appeared to be influenced by the type of acid used to adjust $\mathrm{pH}$ of growth medium. Control populations of L. innocua or E. coli were reduced $(\mathrm{P}<0.05)$ by $1.97-2.09 \log \mathrm{CFU} / \mathrm{ml}$ and 0.81-2.75 $\log \mathrm{CFU} / \mathrm{ml}$, respectively, when $\mathrm{pH}$ was adjusted with lactic or acetic acids compared with $\mathrm{HCl}$ (Figure 3). Lehrke, Hernaez, Mugliaroli, von Staszewski and Jagus (2011) studied the responses of L. innocua to acid stress applied alone or in combination with green tea extract, and reported a synergistic antimicrobial effect of the extract with acidification, especially when the $\mathrm{pH}$ of growth medium was adjusted with lactic or citric acid, compared with medium acidified using $\mathrm{HCl}$. The differences in effect of strong inorganic or weak organic acids may be attributed to different mechanisms of action on bacterial cells. Strong mineral acids dissociate completely into protons and anions. Although the cell membrane has a very low permeability to protons, they can still enter or exit cells by interacting with the cellular proton transport system. To maintain the correct intracellular $\mathrm{pH}$ bacterial cells expend energy, and as a consequence nutrient transport, metabolic activity is affected resulting in extended lag phases, reduced growth rates and cell biomass (Lehrke et al., 2011). In comparison, weak organic acids can penetrate cell membranes in an undissociated form. Inside bacterial cells, higher intracellular $\mathrm{pH}$ causes dissociation of these molecules, releasing protons and acidifying the cytoplasm, which in turn inactivates some metabolic enzymes, impairs membrane function, nutrient transport and overall metabolic activity (Samelis $\&$ Sofos, 2003). Recently nanoencapsulation technology has been used to deliver enhanced antibacterial activity 
from EOs in dilute liquid food systems such as fruit juices (Donsì, Annunziata, Sessa, \& Ferrari, 2011). However, the application of this technology to more complex viscous food products such as ready meals remains to be investigated.
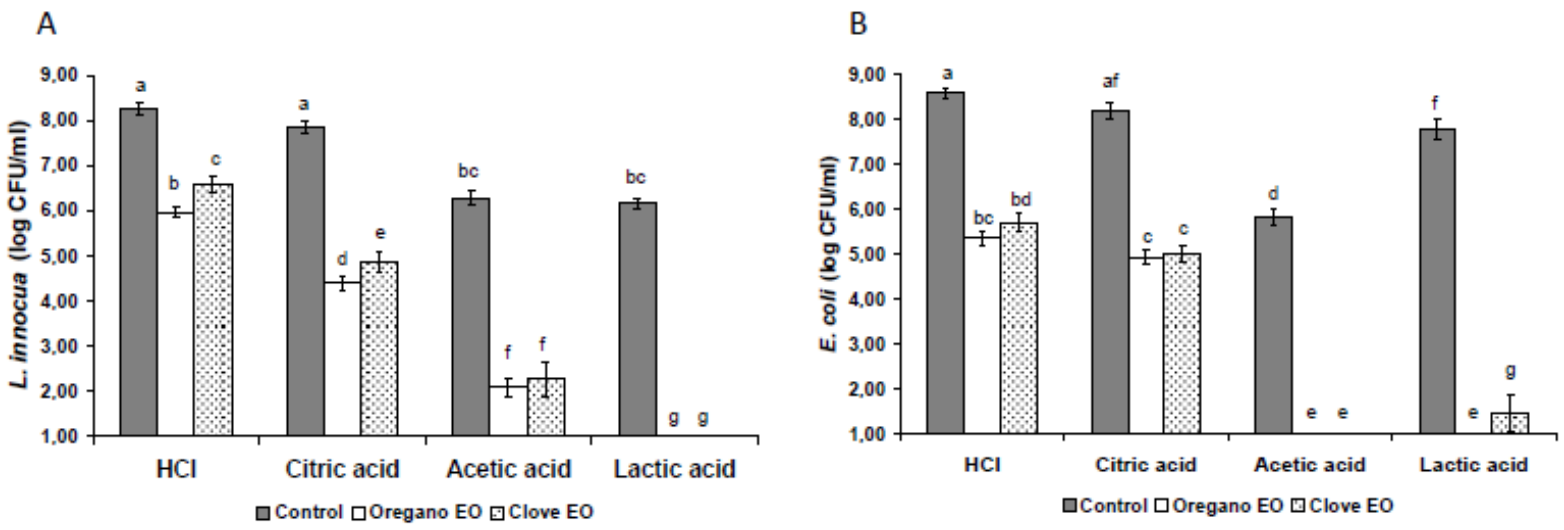

Figure 3. Effect of type of acid used for medium acidification on growth of (A) L. innocua ATCC 33090 or (B) Escherichia coli ATCC 11303 treated with oregano and clove essential oils at MICs. Error bars indicate S. D. Different letters signify statistical differences between values $(\mathrm{P}<0.05)$

\subsection{Application of Oregano Essential Oil in Vegetable Soup With Reformulated Composition During Chilled Storage}

The data obtained in this study on the effect of food ingredients and food properties on antimicrobial efficacy of EOs was used to reformulate the composition of the reduced salt vegetable soup for optimised application in a food product. Oregano EO was selected, based on the slightly stronger antimicrobial properties found compared with clove oil, and its' flavour suitability for inclusion into vegetable soup. Among the food ingredients and food chemical properties tested, $\mathrm{NaCl}$ addition or acidification of growth medium were found to enhance the activity of EOs. The soup used in this study was produced as a low sodium product $(\mathrm{NaCl} 0.46 \mathrm{~g} / 100 \mathrm{~g})$, therefore the salt concentration was not further adjusted. However, reformulation of the soup was undertaken by reducing the $\mathrm{pH}$ to 5.0 using citric acid, as organic acids had contributed to enhanced antimicrobial activity of essential oils and this acid had also been used by the manufacturer of the soup to adjust $\mathrm{pH}$ of other commercial products. A combination of $\mathrm{EO}$ with a reduction in $\mathrm{pH}$ of the soup to 5.0 using citric acid resulted in a significant reduction $(\mathrm{P}<0.05)$ of bacterial counts of L. innocua or E. coli throughout storage, both at the refrigerated temperature of $4{ }^{\circ} \mathrm{C}$ and at an abuse temperature of $10^{\circ} \mathrm{C}$ (Figure 4). Effectiveness of combination treatments is particularly important at $10^{\circ} \mathrm{C}$ storage, which can favour growth of psychrotrophic bacteria including L. monocytogenes to significant numbers food products, making post-process contamination a significant concern for chilled ready meals (Grau \& Vanderlinde, 1992). After 9 days of storage, populations of L. innocua inoculated into acidified soup and treated with $0.25 \mathrm{ml} / 100 \mathrm{~g}$ oregano oil, were reduced to 4.73 and $4.12 \log \mathrm{CFU} / \mathrm{g}$ when stored at $10^{\circ} \mathrm{C}$ or $4^{\circ} \mathrm{C}$, respectively, while control populations inoculated into unadjusted soup with a $\mathrm{pH} 6.2$ without $\mathrm{EO}$ grew to levels of 9.78 or $7.60 \log \mathrm{CFU} / \mathrm{g}$ when stored at $10^{\circ} \mathrm{C}$ or $4^{\circ} \mathrm{C}$, respectively. Similarly, populations of $E$. coli inoculated into a reformulated acidified soup and treated with EO, were reduced to 4.87 or $4.48 \mathrm{log} \mathrm{CFU} / \mathrm{g}$ when stored at $10^{\circ} \mathrm{C}$ or $4^{\circ} \mathrm{C}$, respectively, while control populations inoculated into an unadjusted soup of $\mathrm{pH} 6.2$ without EO were detected at levels of 9.35 or $5.63 \log \mathrm{CFU} / \mathrm{g}$ when stored at $10^{\circ} \mathrm{C}$ or $4{ }^{\circ} \mathrm{C}$, respectively, after 9 days of storage (Figure 4). To our knowledge, the combined effect of EO treatment and acidification with weak organic acid in a reformulated reduced sodium soup product, has not been reported. The antimicrobial efficacy of carvacrol against Staphylococcus aureus was enhanced by simultaneous combination with acetic acid in meat broth (de Oliveira, Stamford, Neto, \& de Souza, 2010). Gutierriez, Barry-Ryan and Bourke (2009) evaluated a number of EO's in broth and model food based media derived from milk, lettuce and beef ingredients and also noted differences in efficacy between data from broth experiments and food based media against a range of pathogens.

The present study has utilised data from broth experiments and applied them to enhance the microbial quality of a reformulated commercially produced reduced salt vegetable soup ready meal. As salt plays a key role in food 
preservation and provides typical organoleptic characteristics in a range of foods, its removal in reduced salt ready meals may have adverse effects on quality of these products. However, our results indicate that combinations of EOs with modification of food composition in reduced sodium chilled ready meal reformulation may allow for application of EOs at low levels for enhanced food safety. This information should be of interest to food manufacturers as targeted reformulation strategies could provide the consumer with safe, high quality, reduced sodium products. Further research will investigate the combined application of essential oils and weak organic acids in different types of chilled meals, as well as sensory acceptability of these reformulated foods.
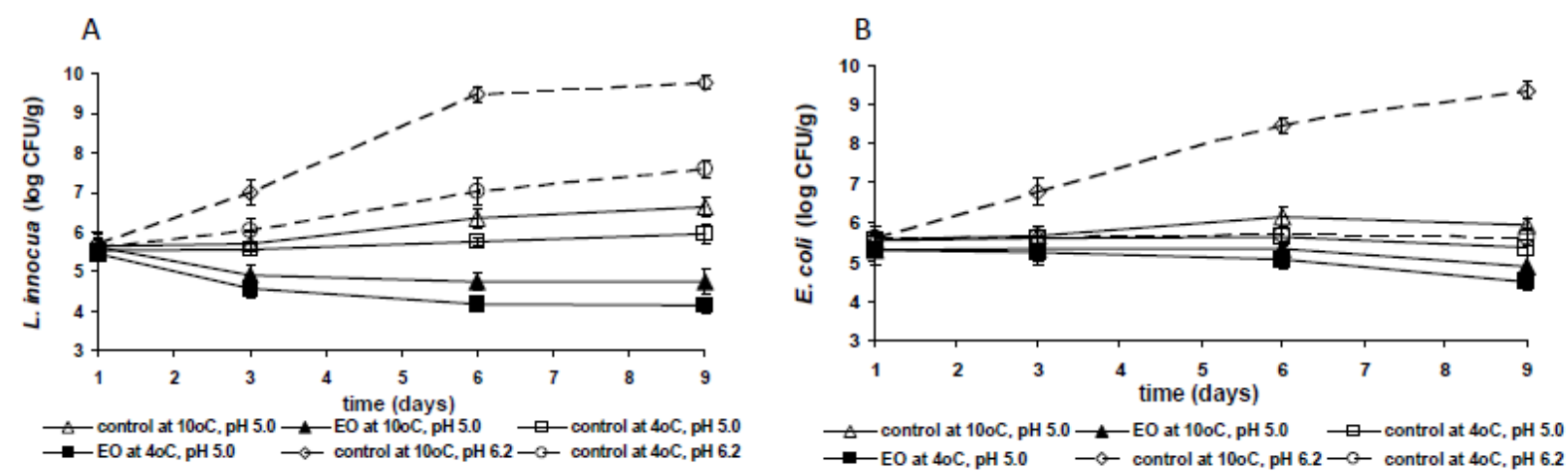

Figure 4. Effect of combined oregano essential oil treatment $(0.25 \mathrm{ml} / 100 \mathrm{~g})$ and reformulation by acidification of a reduced salt vegetable soup on the survival of (A) L. innocua ATCC 33090 and (B) Escherichia coli ATCC 11303 during 9 days of storage: $(-\mathbf{\Delta}-) \mathrm{EO}$ at $\mathrm{pH} 5.0$ at $10{ }^{\circ} \mathrm{C},(-\boldsymbol{-}-) \mathrm{EO}$ at $\mathrm{pH} 5.0$ at $4{ }^{\circ} \mathrm{C}(-\Delta-)$ control at $\mathrm{pH}$ 5.0 at $10^{\circ} \mathrm{C},(-\square-)$ control at $\mathrm{pH} 5.0$ at $4{ }^{\circ} \mathrm{C}\left(---_{--}\right)$control at $\mathrm{pH} 6.2$ at $10^{\circ} \mathrm{C}\left(---_{--}\right)$control at $\mathrm{pH} 6.2$ at $4{ }^{\circ} \mathrm{C}$.

Error bars indicate S. D

\section{Conclusions}

Antimicrobial activity of oregano and clove EOs used in this study were considerably affected by the composition of the suspending medium or variation in food matrix ingredient levels. Antimicrobial activity of EOs against $L$. innocua or E. coli was enhanced in the presence of $\mathrm{NaCl}(\geq 0.5 \mathrm{~g} / 100 \mathrm{ml})$, and in medium with low $\mathrm{pH}$ values $(\leq 5.0)$, especially when adjusted with weak organic acids. Antibacterial activity of EOs was reduced in the presence of vegetable oil, protein and higher concentrations of starch. A combination of oregano EO with reformulation by reduction in $\mathrm{pH}$ of a reduced salt soup to 5.0 using citric acid was effective in controlling and reduction of bacterial growth of L. innocua or E. coli during 9 days storage at 4 or $10{ }^{\circ} \mathrm{C}$. Therefore, a combination of reformulation treatments may be considered as a more natural and attractive alternative to food manufacturers to improve preservation of chilled ready meals, without the use of chemical additives.

\section{Acknowledgements}

This work was funded by the Department of Agriculture, Fisheries and Food, (Agriculture House, Kildare Street, Dublin 2) under Food Institutional Research Measure (FIRM), National Development Plan (NDP) 2000-2006.

\section{References}

Brul, S., \& Coote, P. (1999). Preservative agents in foods: Mode of action and microbial resistance mechanisms. International Journal of Food Microbiology, 50, 1-17. http://dx.doi.org/10.1016/S0168-1605(99)00072-0

Buchanan, R. L., Golden, M. H., \& Whiting, R. C. (1993). Differentiation of the effects of pH and lactic or acetic acid concentration on the kinetics of Listeria monocytogenes inactivation. Journal of Food Protection, 56, 474-478.

Burt, S. (2004). Essential oils: their antibacterial properties and potential applications in foods-a review. $\begin{array}{lllll}\text { International of Journal Food } & \text { Microbiology, } & \text { 94, } & \text { 253. }\end{array}$ http://dx.doi.org/10.1016/j.ijfoodmicro.2004.03.022

Burt, S., \& Reinders, R. D. (2003). Antibacterial activity of selected plant essential oils against Escherichia coli O157:H7. Letters in Applied Microbiology, 162-167. http://dx.doi.org/10.1046/j.1472-765X.2003.01285.x

de Oliveira, C. E., Stamford, T. L., Gomes, N. J., \& de Souza, E. L. (2010). Inhibition of Staphylococcus aureus 
in broth and meat broth using synergies of phenolics and organic acids. International Journal of Food Microbiology, 137, 312-316. http://dx.doi.org/10.1016/j.ijfoodmicro.2009.11.019

Consensus Action on Salt \& Health (CASH). (2012). Salt Awareness Week 2012 - Reducing Salt. Preventing Stroke, Retrieved 15 April, 2014, from http://www.worldactiononsalt.com/docs/saltawareness/76906.pdf

Deans, S. G., \& Ritchie, G. (1987). Antibacterial properties of plant essential oils. International Journal of Food Microbiology, 5(2), 165-180. http://dx.doi.org/10.1016/0168-1605(87)90034-1

Desmond, E. (2006). Reducing salt: A challenge for the meat industry. Meat Science, 74, 188-196. http://dx.doi.org/10.1016/j.meatsci.2006.04.014

Devlieghere, F., Vermeulen, A., \& Debevere, J. (2004). Chitosan: antimicrobial activity, interactions with food components and applicability as a coating on fruit and vegetables. Food Microbiology, 21, 703-714. http://dx.doi.org/10.1016/j.fm.2004.02.008

Donsì, F., Annunziata, M., Sessa, M., \& Ferrari, G. (2011). Nanoencapsulation of essential oils to enhance their antimicrobial activity in foods. LWT-Food Science and Technology, 44, 1908-1914. http://dx.doi.org/10.1016/j.lwt.2011.03.003

Garcia-Gonzalez, L., Geeraerd, A. H., Elst, K., Van Ginneken, L., Van Impe, J. F., \& Devlieghere, F. (2009). Influence of type of microorganism, food ingredients and food properties on high-pressure carbon dioxide inactivation of microorganisms. International Journal of Food Microbiology, 129, 253-263. http://dx.doi.org/10.1016/j.ijfoodmicro.2008.12.005

FSAI. (2003). Salt and Health: Review of the Scientific Evidence and Recommendations for Public Policy in Ireland. Food Safety Authority of Ireland.

FSAI. (2005). Salt and health: review of the scientific evidence and recommendations for public policy in Ireland. Food Safety Authority of Ireland.

Glass, K. A., \& Johnson, E. A. (2004). Antagonistic effect of fat on the antibotulinal activity of food preservatives and fatty acids. Food Microbiology, 21, 675-682. http://dx.doi.org/10.1016/j.fm.2004.03.002

Grau, F. H., \& Vanderlinde, P. B. (1992). Occurrence, numbers, and growth of Listeria monocytogenes on some vacuum-packaged processed meats. Journal of Food Protection, 55, 4-7.

Gutierrez, J., Barry-Ryan, C., \& Bourke, P. (2008). The antimicrobial efficacy of plant essential oil combinations and interactions with food ingredients. International Journal of Food Microbiology, 124, 91-97. http://dx.doi.org/10.1016/j.ijfoodmicro.2008.02.028

Gutierrez, J., Barry-Ryan, C., \& Bourke, P. (2009). Antimicrobial activity of plant essential oils using food model media: Efficacy,synergistic potential and interactions with food components. Food Microbiology, 26, 142-150. http://dx.doi.org/10.1016/j.fm.2008.10.008

Harpaz, S., Glatman, L., Drabkin, V., \& Gelman, A. (2003). Effects of herbal essential oils used to extend the shelf life of freshwater-reared Asian sea bass fish (Lates calcarifer). Journal of Food Protection, 66, 410-417.

Holley, R. A., \& Patel, D. (2005). Improvement in shelf-life and safety of perishable foods by plant essential oils and smoke antimicrobials. Food Microbiology, 22, 273-292. http://dx.doi.org/10.1016/j.fm.2004.08.006

Hsieh, P.-Ch., Mau, J.-L., \& Huang, Sh.-H. (2001). Antimicrobial effect of various combinations of plant extracts. Food Microbiology, 18, 35-43. http://dx.doi.org/10.1006/fmic.2000.0376

Juven, B. J., Kanner, J., Schved, F., \& Weisslowicz, H. (1994). Factors that interact with the antibacterial action of thyme essential oil and its active constituents. Journal of Applied Bacteriology, 76, 626-631. http://dx.doi.org/10.1111/j.1365-2672.1994.tb01661.x

Karatzas, A. K., Kets, E. P. W., Smid, E. J., \& Bennik, M. H. J. (2001). The combined action of carvacrol and high hydrostatic pressure on Listeria monocytogenes Scott A. Journal of Applied Microbiology, 90, 463-469. http://dx.doi.org/10.1046/j.1365-2672.2001.01266.x

Lehrke, G., Hernaez, L., Mugliaroli, S. L., von Staszewski, M., \& Jagus, R. J. (2011). Sensitization of Listeria innocua to inorganic and organic acids by natural antimicrobials. LWT - Food Science and Technology, 44, 984-991. http://dx.doi.org/10.1016/j.lwt.2010.09.016

Lv, F., Liang, H., Yuan, Q., \& Li, C. (2011). In vitro antimicrobial effects and mechanism of action of selected plant essential oil combinations against four food-related microorganisms. Food Research International, 44, 3057-3064. http://dx.doi.org/10.1016/j.foodres.2011.07.030

MacGregor, G. A., \& de Wardener, H. E. (2000). "Salt": A commentary. American Journal of Hypertension, 13, 313-316. 
Mejlholm, O., \& Dalgaard, P. (2002). Antimicrobial effect of essential oils on the seafood spoilage micro-organism Photobacterium phosphoreum in liquid media and fish products. Letters in Applied Microbiology, 34, 27-31. http://dx.doi.org/10.1046/j.1472-765x.2002.01033.x

Menon, K. V., \& Garg, S. R. (2001). Inhibitory effect of clove oil on Listeria monocytogenes in meat and cheese. Food Microbiology, 18, 647-650. http://dx.doi.org/10.1006/fmic.2001.0430

Mitchell, M., Brunton., N. P., \& Wilkinson, M. G. (2011). Impact of salt reduction on the instrumental and sensory flavor profile of vegetable soup. Food Research International, 44, 1036-1043. http://dx.doi.org/10.1016/j.foodres.2011.03.007

Mitchell, M., Brunton., N. P., \& Wilkinson, M. G. (2013). The Influence of Salt Taste Threshold on Acceptability and Purchase Intent of Reformulated Reduced Sodium Vegetable Soups. Food Quality and Preference, 28, 356-360. http://dx.doi.org/10.1016/j.foodqual.2012.11.002

Moreira, M. R., Ponce, A. G., del Valle, C. E., \& Roura, S. I. (2005). Inhibitory parameters of essential oils to reduce a foodborne pathogen. LWT - Food Science and Technology, 38, 565-570. http://dx.doi.org/10.1016/j.lwt.2004.07.012

Mytle, N., Anderson, G. L., Doyle, M. P., \& Smith, M. A. (2006). Antimicrobial activity of clove (Syzgium aromaticum) oil in inhibiting Listeria monocytogenes on chicken frankfurters. Food Control, 17, 102-107. http://dx.doi.org/10.1016/j.foodcont.2004.09.008

Pandit, V. A., \& Shelef, L. A. (1994). Sensitivity of Listeria monocytogenes to rosemary (Rosmarinus officinalis L.). Food Microbiology, 11, 57-63. http://dx.doi.org/10.1006/fmic.1994.1008

Prakash, B., Singh, P., Kedia, A., \& Dubey, N. K. (2012). Assessment of some essential oils as food preservatives based on antifungal, antiaflatoxin, antioxidant activities and in vivo efficacy in food system. Food Research International, 49, 201-208. http://dx.doi.org/10.1016/j.foodres.2012.08.020

SACN. (2003). Salt and Health. Scientific Advisory Committee on Nutrition. Retrieved 23, May 2014, from http://www.sacn.gov.uk/pdfs/sacn_salt_final.pdf

Samelis, J., \& Sofos, J. N. (2003). Organic acids. In S. Roller (Ed.), Natural antimicrobials for the minimal processing of foods (pp. 98-132). Cambridge, England: Woodhead Publishing Ltd. http://dx.doi.org/10.1093/nar/gkg784

Smith-Palmer, A., Stewart, J., \& Fyfe, L. (1998). Antimicrobial properties of plant essential oils and essences against five important food-borne pathogens. Letters in Applied Microbiology, 26, 118-122. http://dx.doi.org/10.1046/j.1472-765X.1998.00303.x

Smith-Palmer, A., Stewart, J., \& Fyfe, L. (2001). The potential application of plant essential oils as natural food preservatives in soft cheese. Food Microbiology, 18, 463-470. http://dx.doi.org/10.1006/fmic.2001.0415

Spencer, C. M., Cai, Y., Martin, R., Gaffney, S. H., Goulding, P. N., Magnolato, D., ... Haslam, E. (1988). Polyphenol complexation-some thoughts and observations. Phytochemistry, 27, 2397-2409. http://dx.doi.org/10.1016/0031-9422(88)87004-3

Ultee, A., \& Smid, E. J. (2001). Influence of carvacrol on growth and toxin production by Bacillus cereus. $\begin{array}{lllll}\text { International Journal of Food } & \text { Microbiology, }\end{array}$ http://dx.doi.org/10.1016/S0168-1605(00)00480-3

Wendakoon, C. N., \& Sakaguchi, M. (1993). Combined effect of sodium-chloride and clove on growth and biogenic-amine formation of Enterobacter aerogenes in mackerel muscle extract. Journal of Food Protection, 56, 410-413.

Witkowska, A. M., Hickey, D. K., Alonso-Gomez, M., \& Wilkinson, M. G. (2013). Evaluation of Antimicrobial Activities of Commercial Herb and Spice Extracts against selected Food-Borne Bacteria. Journal of Food Research, 2, 37-54. http://dx.doi.org/10.5539/jfr.v2n4p37

\section{Copyrights}

Copyright for this article is retained by the author(s), with first publication rights granted to the journal.

This is an open-access article distributed under the terms and conditions of the Creative Commons Attribution license (http://creativecommons.org/licenses/by/3.0/). 